\title{
$\mathrm{LCC}$ 분석을 통한 도시철도 전동차의 경제적 사용내구년한 추정 (서울메트로 사례를 중심으로)
}

\section{Estimation of the Life-span for Urban Rolling Stock through LCC Analysis (Focused on Seoul Metro)}

\author{
정수영* · 이원영 \\ Su Young Chung $\cdot$ Won Young Lee
}

\begin{abstract}
The lifespan of a rolling stock is limited to 25 years by the urban railway law. But it can be extended to 40 years by conducting the regular safety test. This gives additional 15 years of lifespan. In Seoul Metro, Many of the rolling stocks were already replaced with new types in 1996 and 2008. New type - VVVF rolling stocks have better safety, maintainability, durability than old types. For this reason, it is desirable to extend the lifespan of new type-rolling stocks. In this paper, we investigated the economical lifespan using LCC (Life Cycle Cost) analysis. This study shows that the economical lifespan comes out 41 years when extra $10 \%$ cost has been considered after 25 years of the train service and 46 years when extra $10 \%$ cost not considered.
\end{abstract}

Keywords : LCC(Life Cycle Cost), Economical lifespan

초 록 전동차의 사용내구년한은 도시철도법에 의해 25 년으로 되어있다. 그 사용제한에 의해 전동차 성능이 양 호해도 사용연장을 위해서는 정밀안전진단을 받아야 한다. 사용내구연한의 연장은 내구년한 만료일의 다음 날 부터 15 년의 범위에서 정밀진단자가 인정하는 기간까지로 규정되어있다. 서울메트로 전동차의 일부가 25년간의 법정 사용내구년한을 채우고 1996년과 2008년에 신형전동차로 교체되었다. 교체된VVVF제어 신형전동차는 구 형전동차에 비해서 안전성·유지보수성·내구성이 향상되어 그 성능에 알맞은 내구년한 설정이 필요하다. 본 논 문에서는 $\mathrm{LCC}$ 분석을 통하여 적정한 전동차의 경제적내구년한을 산출하였다. 25 년부터 유지보수비용가중치 $10 \%$ 를 고려할 때에는 41 년, 고려하지 않을 때에는 46년의 결과가 얻어졌다.

주요어 : 생애주기비용, 경제적내구년한

\section{1. 서 론}

\section{1 연구의 배경 및 목적}

현재 전동차 등 도시철도차량의 사용내구년한은 도시철도 법 관련규정으로 정해져있다. 2009년 도시철도법의 개정에 의해 도시철도차량의 사용내구년한은 신규제작 철도차량의 경우 발주 시 제작사양서에 명시한 수명까지로 하되, 수명 이 명시되지 아니한 경우에는 25년으로한다」로 규정되어 있다. 한편 동 규칙에는 「정밀진단자가 실시하는 정밀진 단결과 안전 운행에 적합하다고 인정된 도시철도차량에 대 한 사용내구연한의 연장은 그 도시철도차량의 사용내구년한 만료일의 다음날 부터 15년의 범위 내에서 정밀진단자가 인 정하는 기가까지로 한다」[1]고 규정되어 총 40년의 사용기 간으로 제한하여 운영상의 경제성과 전동차의 안전성 양면 을 고려하고 있다. 서울메트로에서는 1974년에 도입되어 25

*Corresponding author.

Tel.: +82-2-6110-5014, E-mail : syc8102@naver.com

(C) The Korean Society for Railway 2012

http://dx.doi.org/10.7782/JKSR.2012.15.5.508
년간 운행되었던 1호선 전동차와 1980년 초에 도입되어 운 행되었던 2·3호선 전동차의 일부가 25년간 운행되었던 1 호선 전동차와 1980 년 초에 도입되어 운행되었던 $2 \cdot 3$ 호선 전동차의 일부가 25 년간의 법정 사용내구년한을 채우고 1996 년과 2005 2008년에 신형전동차로 교체되었다. 교체된 신 형전동차는 VVVF(Variable Voltage Variable Frequency)제 어 전동차로서 연강골조 대신 스테인레스 차체로 부식량의 절대 감소, 차체 경량화 등의 장점으로 교체된 구형전동차 에 비해서 안전성·유지보수성·내구성이 많이 향상되었다. 따라서 자원 및 비용절약 차원에서 전동차의 사용내구년한 의 연장이 필요하다. 본 논문은 $\mathrm{VVVF}$ 제어전동차의 도입 부터 폐기까지 구입비용과 유지보수비용 등 전 생애주기 동 안의 비용을 분석해서 경제적인 전동차 사용내구년한을 추 정하는 데 목적이 있다.

\section{2 연구의 범위 및 절차}

연구범위는 서울메트로에 1996년 이후 도입되어 운행되는 제3세대 VVVF제어 전동차를 분석대상으로 하였다. 서울메 트로에서는 현재 1954량 200 편성 [일산선포함 2114량 216 
편성]의 전동차가 1 4호선에서 운행되고 있다. 제 1 세대 저 항제어 전동차는 사용내구년한에 의하여 교체되었고, 제2세 대 쵸파 (Chopper)제어전동차도 교체되었거나 일부 운행되 고 있다. 현재는 1995년부터 운행 중인 제3세대 VVVF 제 어전동차 1426 량이 대부분을 차지하고 있다.

본 연구는 Fig. 1 절차에 따라 진행한다.

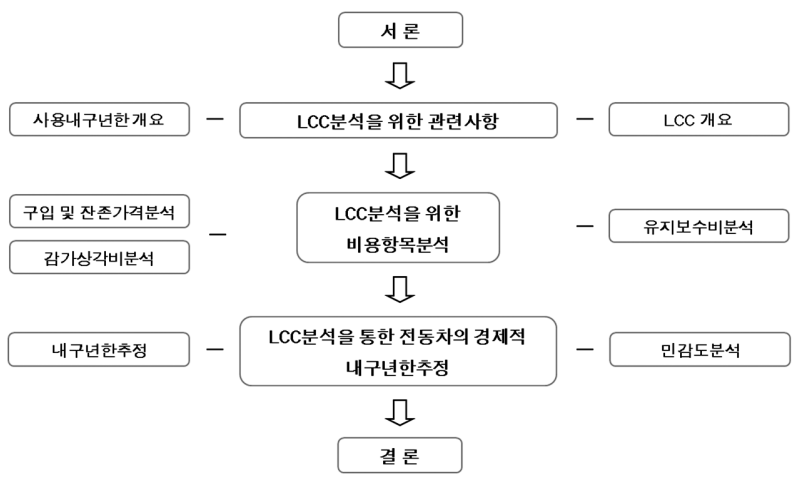

Fig. 1 Process of study

\section{2.전동차 LCC(LifeCycleCost) 분석을 위한 관련사항}

\section{1 전동차 사용내구년한}

전동차의 사용내구년한은 신뢰성(reliaibility)·가용성(availability)·정비성(maintainability)의 목표값을 충족하고 안전성 이 보장되는 사용한계를 말하는 것으로, 그 사용한계는 철 도안전법에 근거한「도시철도차량관리규칙」에 의거 '신 규제작 철도차량은 제작사양서에 명시한 수명까지로 하되, 수 명이 명시되지 아니 한 경우에는 25년으로 한다’라고 법정 화 되어있다.

전동차의 내구년한은 물리적(Physical life), 진부적(Commonplace life), 경제적내구년한 (Economic life)으로 정의되며, 물리적내구년한은 내용가능(耐用可能) 한계로 정하는 것을 말하는 것으로 차체와 대차 등 가격측면에서 주체가 되는 주 요부품수명에 따른다. 진부적내구년한(Commonplace life)은 기술진전으로 성능이 뒤떨어져서 신형차로 교환하는 방법이 경영적으로 유리하다는 개념으로 기술진보와 시대의 변혁이 급속하면 짧게 되는 경향이 있다. 경제적내구년한(Economic life)는 전동차 생애주기 동안의 평균유지보수비용(Average Maintenance Cost)과 평균자본비용(Average Capital Cost)과 의 합인 평균총비용(Average Total Cost [LCC])의 최소지점 을 내구년한으로 정하는 개념으로 본 논문의 주제다. 그리 고 그 수명은 물리적내구년한이 가장 길고, 경제적내구년한 이 중간, 진부적내구년한이 가장 짧다[2].

전동차는 시간이 지남에 따라 Fig. 2의 그래프처럼 유지보 수시간과 부품교환 수량의 증가로 유지보수비가 상승하는 반 면 감가상각비는 감소되어서 위에서 정의한대로 경제적내구 년한(Economic life)은 평균총비용(Average Total Cost [LCC]) 이 최소가 되는 지점이다[3].

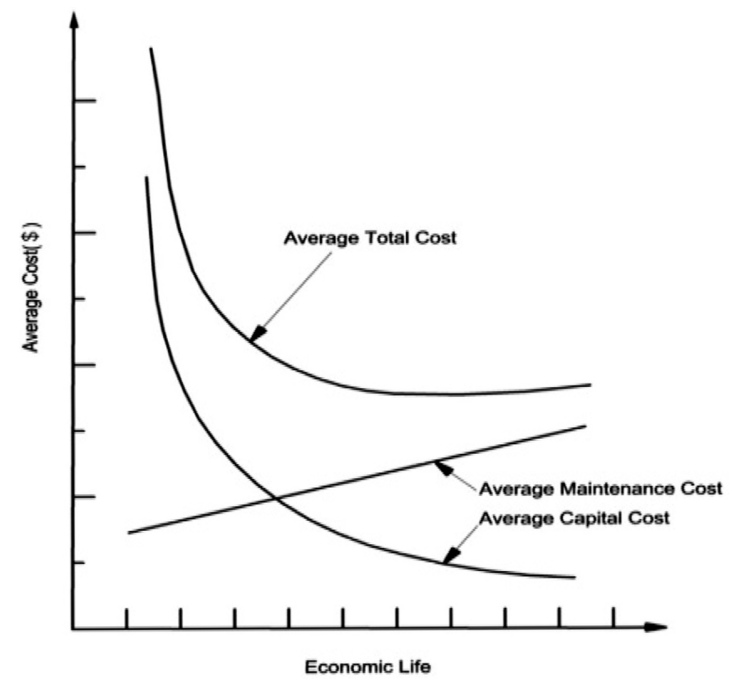

Fig. 2 Optimum economic life(출처: Systems Engineering and Analysis by Benjamin S)

\subsection{LCC(Life Cost Cycle)개요}

일반적으로 시설물·장비의 생애주기비용(Life Cycle Cost) 은 계획단계에서부터 폐기처분 시까지의 모든 비용 즉, 계 획 및 설계비·건설비·운용관리비·폐기물처분비용 등을 합한 것으로 시설물·장비의 공용수명기간 전체에 필요한 모 든 비용을 말하며, 같은 개념으로 전동차 $\mathrm{LCC}$ 는 전동차구 입에서부터 폐기까지 운용기간에 소요되는 경비의 총계이며 그 요소는 전동차 구입가격·감가상각비·유지보수비용(전 력비포함)·잔존가격 등으로 구성된다. 이러한 개념에 따라 LCC 분석이란 총생애주기비용(LCC)을 최소화할 수 있는 최 적대안을 산정하는 공학적 의사결정기법을 말한다.

\section{3 분석을 위한 기본가정}

전동차LCC분석은 전동차 전 생애기간 동안 투입된 모든 비용 즉 구입비용·감가상각비·유지보수비용의 분석이 필 요하며, 특히 유지보수비용은 과거비용을 근거로 미래비용 의 예측이 필요하다. 유지보수비용예측을 위해서는 세 가지 의 가정 즉 전동차사용가능기간·유지보수인원·할인율에 대한 것이 선행되어야 한다.

첫 번째로 전동차의 최대 사용기간은 현재 규정상으로는 정밀안전진단을 거쳐 최장 40 년으로 되어 있다[1]. 전동차 의 교체는 기술진전과 신예차량의 탄생에 의해 진부적내구 년한 기준으로 이루어지므로, 이 기간은 경제적내구년한 범 주 내에서 최장사용 기간이 정해져야 하므로 연구대상 전동 차사용 가능기간을 도입(1996년)부터 50년으로 가정했다.

두 번째로 유지보수인원은 기간에 따라 변동이 있었고, 향 후에도 변동이 예상된다. 비교분석에는 동일조건이 기본전 제이므로 2011년 현재인원 기준으로 하여 50년 동안 동일 인원수로 분석하였다.

세 번째로 할인율이다. LCC분석에는 미래의 발생비용을 
Table 1 Real interest rates

\begin{tabular}{c|c|c|c}
\hline 년도 & $I_{n}(\%)$ & $f(\%)$ & $I_{r}(\%)$ \\
\hline \hline 96 & 11.21 & 4.92 & 6.00 \\
\hline 97 & 11.83 & 4.44 & 7.08 \\
\hline 98 & 15.18 & 7.51 & 7.13 \\
\hline 99 & 9.4 & 0.81 & 8.52 \\
\hline 00 & 8.55 & 2.26 & 6.15 \\
\hline 01 & 7.70 & 4.07 & 3.49 \\
\hline 02 & 6.70 & 2.76 & 3.83 \\
\hline 03 & 6.24 & 3.51 & 2.64 \\
\hline 04 & 5.90 & 3.59 & 2.23 \\
\hline 05 & 5.59 & 2.75 & 2.76 \\
\hline 06 & 5.99 & 2.20 & 3.71 \\
\hline 07 & 6.55 & 2.50 & 3.95 \\
\hline 08 & 7.17 & 4.7 & 2.36 \\
\hline 09 & 5.65 & 2.8 & 2.77 \\
\hline 10 & 5.51 & 2.0 & 2.44 \\
\hline 11 & 5.76 & 4.0 & 1.69 \\
\hline 평균 & $\mathbf{7 . 8}$ & $\mathbf{3 . 5}$ & $\mathbf{4 . 1}$ \\
\hline
\end{tabular}

현재의 가치로 환산하는 과정을 포함한다. 그런데 화폐는 시 간이 지나면 그 가치도 변화하는 특성을 가지고 있다. 따라 서 발생 시점이 다른 화폐의 객관적 비교를 위해서는 특정 시점으로 화폐의 시간가치를 환산해야 하며 이때 환산을 하 기 위해서는 할인율(Discount rates)이 이용된다. 적용될 할 인율은 한국은행의 정기예금 금리 및 소비자 물가지수를 바 탕으로 한 실질할인율(Real discount rates) $4.1 \%$ 로 하였다 [4]. 이 값은 식 (1)에 의하여 Table 1에 나타난 1996년부터 2011년 까지 실질할인율을 구한 평균값이며 실제로 건설사 업 등 장기간 $\mathrm{LCC}$ 분석에 소요되는 실질할인율은 보통 3 5\% 범위에 있다[5].

$$
\begin{aligned}
& I_{r}=\frac{\left(1+I_{n}\right)}{(1+f)}-1 \\
& I_{r}=\text { 실질할인율, } I_{n}=\text { 공칭할인율 }(\text { 은행금리 }), \\
& f=\text { 인플레이션율 }
\end{aligned}
$$

\section{LCC분석을 위한 비용항목}

LCC분석에서 전동차 경제적내구년한(Economic life)은 Fig. 2에서 보는 것처럼 전동차구입가격(Aquisition Price)과 감가상각비 및 전동차의 잔존가격을 포함하여 전 생애기간 동안의 유지보수 비용에 의하여 추정 된다.

\section{1 구입가격 및 잔존가격}

일반적으로 $\mathrm{LCC}$ 분석에서 초기투자비는 연구 개발비·설 계비·제작비 등으로 나누어 지지만 본 논문에서는 전동차
구입가격(Aquisition Price)이 초기투자비에 해당된다. 분석 대상인 전동차의 구입가격((Aquisition Price)은 1996년 당시 편성당 약 69 억5천만원으로 2011 년까지의 실질할인율 $4.1 \%$ 로 기준해서 2011년 현재가치 125억원이다.

$$
\begin{aligned}
& 2011 \text { 년 현재가치가격 } \\
& =6,950,000,000(1+0.041)^{16-1}=12,500,000,000 \text { 원 }
\end{aligned}
$$

잔존가격(Salvage value)은 고정자산의 사용가능기간이 끝 나더라도 그 자산의 잔해를 매각 처분함으로써 얻을 수 있 는 가치를 말하며 이를 잔존가치 또는 잔존가격이라고도 한 다. 잔존가격은 2008년에 교체된 전동차 중 2011년에 매각 된 비용 1 억 5 천만원이다.

\section{2 전동차 감가상각비(Deprecition)}

공장이나 기계설비와 같은 고정자산은 일정기간이 경과하 면 전 기간에 걸쳐서 평균적으로 감가되며 이를 감가상각이 라고 한다. 감가상각비를 계산하는 정액법[6]과 정률법 중 정 액법을 사용하여 계산했고, 감가상각비는 매년 $247,000,000$ 원이다. 매년 감가상각비와 평균자본비용은 Table 2 과 같이 구해진다.

$$
\begin{aligned}
& \text { 감가상각비 }=\frac{\text { 고정자산취득원가-잔존가격 }}{\text { 내용연수 }} \\
& =\frac{12,500,000,000-150,000,000}{50}=247,000,000
\end{aligned}
$$

\section{3 전동차 유지보수비용}

전동차의 유지보수는 예방정비(Prevent maintenance)를 기 본으로 주기적으로 수행된다. 유지보수는 경정비와 중정비 의 명칭으로 수행되고, 해당되는 비용항목은 인건비·경비 등으로 Table 3 과 같다. LCC분석은 전 생애기간 동안의 모 든 비용인 전동차구입비·감가상각비·유지보수비용분석에 의하여 수행되는데 유지보수비용은 데이터의 신뢰성을 높이 기 위하여 도입부터 16 년동안 시행된 16 개 편성분에 대한 유지보수비용을 조사하여 1 개 편성분의 평균유지 보수비용 을 산정하였고, 이를 기준으로 50년 간의 유지보수비용을 예 측하였다.

\subsection{1 유지보수비용분석[1년차 16년차]}

전동차 도입부터 16년 차까지 유지보수 수행인력은 2011 년 기준 인원으로 계산하였고, 유지보수비용은 1 개 편성 (10 량)에 대한 년간 유지보수비용이다. 해당년도 유지보수비용 은 Table 4에서 보여지는 것처럼 1996년 171,074천원, 1997 년 290,710천원, 1998년 451,707천원으로 나타났다. 비용이 나 편익은 동일 조건의 불변비용으로 계산되어 분석되어야 한다. 따라서 식 (2)과 같이 연금 미래가치(Future Value)[7] 계산에 주로 쓰이는 공식을 사용하여 할인율 $4.1 \%$ 를 적용 해서 각 해당년도의 비용을 2011년 동일가치(불변가) 비용 인 실질현금흐름(Real cash flow)으로 계산했다. Table 4의 1996년부터 2011년의 당년도 비용 171,074천원부터 922,163 
LCC분석을 통한 도시철도 전동차의 경제적 사용내구년한 추정(서울메트로 사례를 중심으로) 한국철도학회논문집 제15권 제5호(2012년 10월) 511

Table 2 Depreciation[W]

\begin{tabular}{c|c|c|c|c}
\hline $\begin{array}{c}\text { 년차 } \\
(\mathrm{A})\end{array}$ & $\begin{array}{c}\text { 구입비용 } \\
(\mathrm{B})\end{array}$ & $\begin{array}{c}\text { 감가상각비 } \\
(\mathrm{C})\end{array}$ & $\begin{array}{c}\text { 잔존가격 } \\
(\mathrm{D})\end{array}$ & $\begin{array}{c}\text { 평균자본비용 } \\
\text { Average Capital Cost }) \\
(\mathrm{E})=(\mathrm{C}+\mathrm{D}) / \mathrm{A}\end{array}$ \\
\hline \hline 1 & $12,500,000,000$ & $247,000,000$ & $12,253,000,000$ & $12,500,000,000$ \\
\hline 4 & & $247,000,000$ & $11,512,000,000$ & $3,125,000,000$ \\
\hline 5 & & $247,000,000$ & $11,265,000,000$ & $2,500,000,000$ \\
\hline 7 & & $247,000,000$ & $10,771,000,000$ & $1,785,714,286$ \\
\hline 10 & & $247,000,000$ & $10,030,000,000$ & $1,250,000,000$ \\
\hline 14 & & $247,000,000$ & $9,042,000,000$ & $892,857,143$ \\
\hline 18 & & $247,000,000$ & $8,054,000,000$ & $694,444,444$ \\
\hline 22 & & $247,000,000$ & $7,066,000,000$ & $568,181,818$ \\
\hline 24 & & $247,000,000$ & $6,572,000,000$ & $520,833,333$ \\
\hline 28 & & $247,000,000$ & $5,584,000,000$ & $446,428,571$ \\
\hline 30 & & $247,000,000$ & $5,090,000,000$ & $416,666,667$ \\
\hline 32 & & $247,000,000$ & $4,596,000,000$ & $390,625,000$ \\
\hline 36 & & $247,000,000$ & $3,608,000,000$ & $347,222,222$ \\
\hline 40 & & $247,000,000$ & $2,620,000,000$ & $312,500,000$ \\
\hline 44 & & $247,000,000$ & $1,632,000,000$ & $284,090,909$ \\
\hline 46 & & $247,000,000$ & $1,138,000,000$ & $271,739,130$ \\
\hline 50 & & $247,000,000$ & $150,000,000$ & $250,000,000$ \\
\hline
\end{tabular}

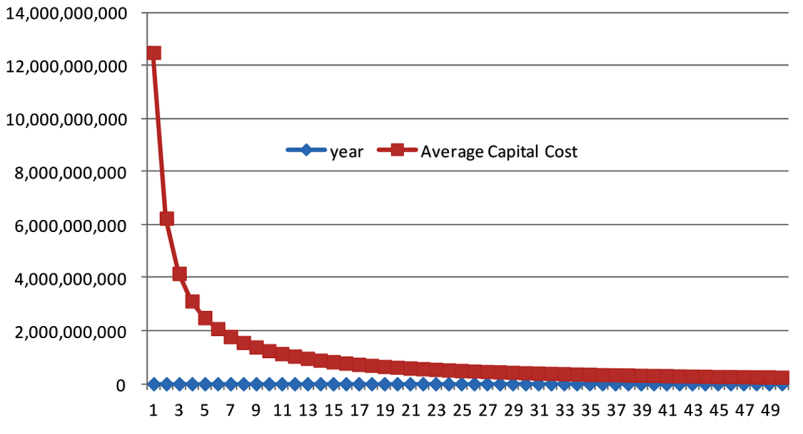

Fig. 3 Graph of average capital cost

Table 3 Maintenance cost item of rolling stock

\begin{tabular}{|c|c|c|}
\hline \multicolumn{2}{|c|}{ 검사종류 및 구성요소 } & 항목 \\
\hline \multirow{3}{*}{$\begin{array}{c}\text { 경수선 및 } \\
\text { 중수선 }\end{array}$} & 인건비 & 검사 및 유지보수비용 \\
\hline & 경비 & 전력비 수도광열비 · 운반비용 \\
\hline & 재료비 & $\begin{array}{c}\text { 도착 · 일상 · 월상검사비용 } \\
\text { /중간 · 전반 · 특별 · 차륜교환검사비용 }\end{array}$ \\
\hline \multicolumn{2}{|c|}{ 일반경비 } & 임원급료, 세금공과, 보험료 등 \\
\hline \multicolumn{2}{|c|}{ 전동차 청소비 등 } & 전동차 청소 및 방역비용 \\
\hline
\end{tabular}

천원은 식 (2)에 의하여 각각 2011년 가치비용으로 1996년 은 312,568천원, 1997년은 510,235천원, 2011년은 922,163 천 원으로 계산된다.
$F V=C_{1}(1+r)^{n-1}+C_{2}(1+r)^{n-2}+\ldots+C_{n-1}(1+r)+{ }_{16} C^{n-16}$

$(C=$ 현금흐름, $r=$ 실질할인율, $n=$ 만기까지의 기간 (n=16.......1: (1996년.......2011년)

1996년도 유지보수비용의 2011년 현재가치비용 $=171,074,000(1+0.041)^{16-1}=312,568,794$ 원

1997년도 유지보수비용의 2011년 현재가치비용 $=290,710,000(1+0.041)^{16-2}=510,235,528$ 원

2011년도 유지보수비용의 2011년 현재가치비용 $=922,163,223(1+0.041)^{16-16}=922,163,223$ 원

1996년 도입부터 2011년 현재까지16년 동안 비용은 Table 4에 나타난 것처럼 년간 평균유지보수비용이 837,921천원으 로 나타났고, 전동차 도입 초기년도 1996년과 1997년의 1,2 년 차에는 하자보증기간으로 유지보수비용이 적게 투입되었 고, 중수선 기간이 도래하지 않아서 각각 312,568 천원 과 510,235 천원으로 정상적인 유지보수가 시행된 1998년 이후 보다 적게 투입되었다.

중수선을 포함한 유지보수 전 과정이 수행되는 1998년에 는 761,581천원, 1999년 2000년도에 각각 767,312천원, 834,890 천원이 소요되었고, 그 후 2001년에 906,599천원, 2002년에 958,577천원, 929,349천원으로 Table 4에서 보는 것처럼 일부를 제외하고는 일반적으로 증가추세를 보이고 있 다. 그러나 2008년도 13 년 차에는 전동차의 중정비 검사주 
Table 4 Rolling stock maintenance cost per year (1000W)

\begin{tabular}{c|c|c}
\hline 년도 & 당년도 비용 & $\begin{array}{c}2011 \text { 년비용 } \\
(4.1 \% \text { 적용) }\end{array}$ \\
\hline \hline (1)'96 & 171,074 & 312,568 \\
\hline (2)'97 & 290,710 & 510,235 \\
\hline (3)'98 & 451,707 & 761,581 \\
\hline (4)'99 & 473,765 & 767,312 \\
\hline (5)'00 & 536,625 & 834,890 \\
\hline (6)'01 & 606,608 & 906,599 \\
\hline (7)'02 & 667,683 & 958,577 \\
\hline (8)'03 & 673,865 & 929,349 \\
\hline (9)'04 & 710,861 & 941,759 \\
\hline (10)'05 & 743,137 & 945,743 \\
\hline (11)'06 & 774,910 & 947,338 \\
\hline (12)'07 & 811,442 & 952,929 \\
\hline (13)'08 & 774,307 & 873,505 \\
\hline (14) '09 & 868,861 & 941,568 \\
\hline (15)'10 & 865,147 & 900,618 \\
\hline (16) '11 & 922,163 & 922,163 \\
\hline $\mathbf{1 6}$ 년간 1편선/1년 평균유지보수비용 & $\mathbf{8 3 7 , 9 2 1}$ \\
\hline
\end{tabular}

기가 2년 검사(2Y)에서 3 년 검사(3Y)로 조정되어 유지보수 비용이 감소되었다. 검사주기가 조정 된 2008년에는 873,505 천원으로 일시적으로 감소되다가 그 후 3 년 검사 $(3 \mathrm{Y})$ 가 정
Table 5 Heavy maintenance cost trend of old type rolling stocks [W]

\begin{tabular}{|c|c|c|c|c|}
\hline 호선 & 년차 & 유지보수비용 & 증가 & 증가율 \\
\hline \multirow{5}{*}{1} & 18 년차 & $561,501,340$ & - & - \\
\hline & 20년차 & $585,911,146$ & $24,409,806$ & $4.3 \%$ \\
\hline & 22년차 & $605,136,367$ & $19,225,221$ & $3.2 \%$ \\
\hline & 24년차 & $1,019,445,463$ & $414,309,096$ & $68 \%$ \\
\hline & \multicolumn{3}{|c|}{ 평 균 } & $25 \%$ \\
\hline \multirow{2}{*}{2} & 20년차 & $543,917,285$ & - & - \\
\hline & 22년차 & $647,728,688$ & $10,381,403$ & $16 \%$ \\
\hline \multirow{2}{*}{3} & 22년차 & $554,261,598$ & - & - \\
\hline & 24년차 & $647,429,794$ & $93,168,196$ & $14 \%$ \\
\hline
\end{tabular}

출처 : 서울메트로 내부자료

착되는 2010년과 2011년에 각각 900,618천원, 922,163 천원 으로 나타났다.

\subsection{2 유지보수비용분석[17차 50년차]}

$\mathrm{LCC}$ 분석은 전 생애기간 동안의 유지보수비용분석이 필요 하여 비용분석을 3 단계로 나누어서 분석했다. 1 단계에서는 1 16년 동안의 유지보수비용실적을 분석하여 해당년도의 비 용을 2011년 가치로 환산하였고, 2단계에서는 1단계에서 분 석된 1 16년간의 유지보수 실적비용을 기초로 시계열분석 (Time series analysis)[8] 방법인 Excel의 Forecast 함수식(기 존값으로 미래의 값을 계산하거나, 예측할 수 있는 함수)을 사용하여 17년차부터 50년차까지 유지보수비용을 예측하였 다. 이 계산 은 Table 6과 Table 8의 (B)열 1 16년차의 유

Table 6 Rolling stocks maintenance cost for 50 year/train-set [W]

\begin{tabular}{c|c|c|c|c|c|c}
\hline \multicolumn{2}{c|}{ 차령/year } & $\begin{array}{c}\text { 유지보수비용 } \\
\text { (Maintenance cost) }\end{array}$ & $\begin{array}{c}\text { 가중치 } 10 \% \\
(10 \% a d d e d ~ f r o m 25 y)\end{array}$ & $\begin{array}{c}\text { 안전진단비용 } \\
\text { (safety cost) }\end{array}$ & $\begin{array}{c}\text { 누적유지보수비용 } \\
\text { (cumulative M/C) }\end{array}$ & $\begin{array}{c}\text { 평균유지보수비용 } \\
\text { (Average Maintenance Cost) }\end{array}$ \\
\hline \hline (A) & - & $(\mathrm{B})$ & $(\mathrm{C})$ & $(\mathrm{D})$ & $(\mathrm{E})=\Sigma(\mathrm{B})+(\mathrm{C})+(\mathrm{C})$ & $(\mathrm{F})=(\mathrm{E}) /(\mathrm{A})$ \\
\hline 1 & $' 96$ & $312,568,794$ & 0 & 0 & $312,568,794$ & $312,568,794$ \\
\hline 2 & $' 97$ & $510,235,528$ & 0 & 0 & $822,804,322$ & $411,402,161$ \\
\hline 3 & $' 98$ & $761,581,554$ & 0 & 0 & $2,351,698,700$ & $528,128,626$ \\
\hline 4 & $' 99$ & $767,312,824$ & 0 & 0 & $3,186,589,356$ & $637,317,871$ \\
\hline 5 & $' 00$ & $834,890,656$ & 0 & 0 & $7,868,619,203$ & $786,861,920$ \\
\hline 10 & $' 05$ & $945,743,801$ & 0 & 0 & $11,583,960,318$ & $827,425,737$ \\
\hline 14 & $' 09$ & $941,568,599$ & 0 & 0 & $12,484,579,222$ & $832,305,281$ \\
\hline 15 & $' 10$ & $900,618,904$ & 0 & 0 & $13,406,742,445$ & $837,921,403$ \\
\hline 16 & $' 11$ & $922,163,223$ & 0 & 0 & $17,570,183,543$ & $878,509,177$ \\
\hline 20 & $' 15$ & $1,029,585,264$ & 0 & $1,584,385,877$ & $925,666,187$ \\
\hline 25 & $' 20$ & $1,065,450,524$ & $106,545,052$ & $250,000,000$ & $23,141,654,670$ & $935,739,596$ \\
\hline 26 & $' 21$ & $1,079,613,473$ & $107,961,347$ & 0 & $24,329,229,490$ & $978,079,117$ \\
\hline 30 & $' 25$ & $1,133,188,110$ & $113,318,811$ & $100,000,000$ & $29,342,373,513$ & $1,019,867,791$ \\
\hline 35 & $' 30$ & $1,176,854,633$ & $117,685,463$ & 0 & $35,695,372,678$ & $1,059,154,531$ \\
\hline 40 & $' 35$ & $1,234,136,646$ & $123,413,665$ & 0 & $42,366,181,258$ & $1,095,869,006$ \\
\hline 45 & $' 40$ & $1,283,308,024$ & $128,330,802$ & 0 & $49,314,105,266$ & $1,131,228,261$ \\
\hline 50 & $' 45$ & $1,339,201,322$ & $133,920,132$ & 0 & $56,561,413,071$ & \\
\hline
\end{tabular}




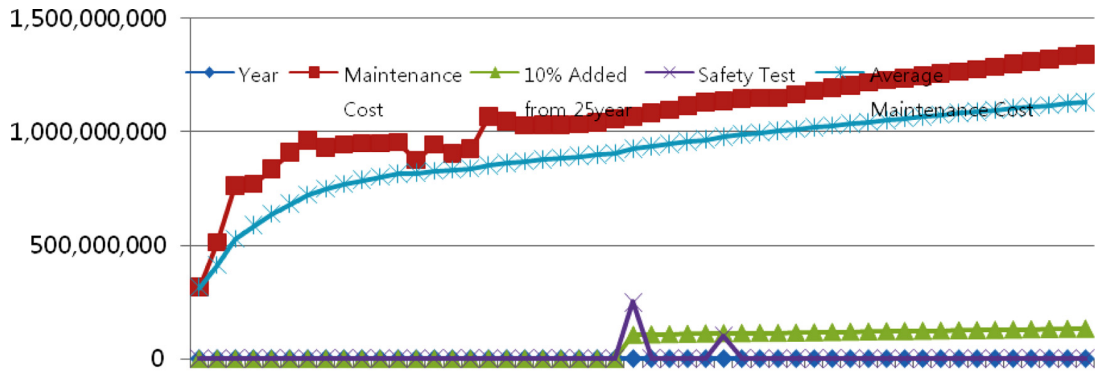

$133577 \quad 91113151719212325272931333537394143454749$

Fig. 4 Graph of rolling Stocks maintenance cost for 50 year/trainset

지보수비용이 Forecast(x,known_y's,known_x's) 식에 의하여 Tables 6과 Table 8의 (B)열 17 50년의 예측비용으로 산출 된다(x: 비용예측데이터, $\mathrm{y}^{\prime} \mathrm{s}$ : 비용데이터의 종속배열, $\mathrm{x}$ 's: 기 간데이터의 독립배열).

한편 전동차 관련규정에는 전동차사용 25 년차에 내구년한 의 연장여부를 확인하기 위하여 정밀진단이 이루어지는데 지 정기관에서 시행하는 25 년차 안전진단비용 2.5 억원과[9] 운 영사 자체에서 시행하는 30 년차 안전진단비용 1 억원을 합 산하였다. 그리고 25 년차부터 매년 유지보수비용 $10 \%$ 를 두 가지로 이유로 가중하여 계산하였다. 그 첫 번째 이유로 Table 5 에서 보는 것처럼 $1 \cdot 2 \cdot 3$ 호선 전동차 중정비의 경우 유 지보수비용(1개편성기준)이 20년차 이후 급격 하게 증가되 는 것을 볼 수 있다. 이러한 현상을 고려하여 유지보수비용 을 가중하였고, 두 번째 이유로 철도안전법 시행규칙제 2 조 「안전관리규정」에 근거한 서울메트로의「안전관리규정」 에는 장기간사용하는 노후전동차는 노후화에 따른 특별한 예 방정비와 주요부품의 성능개선을 하여야 한다고 규정되어 25 년 이내의 전동차 운영체계에 비해서 검사주기와 검사방법 이 강화된다.

이에 따라서 전동차 성능유지를 위해서는 검사주기 및 유 지보수 활동증가, 부품교환 수량증가로 비용의 추가적 비용 상승이 예상된다. 이와같은 이유로 유지보수 비용의 변수를 고려하여 25년차부터 매년 유지보수비용 $10 \%$ 가중하여 계 산하였다. 동시에 유지보수비용 변동을 고려하여 $10 \%$ 가중 치 이외에 $0 \%$ 가중치와 $5 \%$ 가중치에 대한 민감도분석도 수 행하였다.

3 단계에서는 유지보수비용·안전진단비용·유지보수비용 가중치를 누적하였고 누적된 비용을 평균값으로 산출하였다. 예측결과 평균유지보수비용은 Table 6,8 과 같이 25 년차는 925,666 천원, 30 년차는 978,079 천원, 40 년차에는 $1,095,869$ 천원으로 점진적인 증가세로 보이고 있다

\section{LCC분석을 통한 전동차의 경제적사용 내구년한 추정}

\section{1 경제적 사용년한 추정}

전동차의 사용기간을 50 년으로 가정했고, 사용개시 후 25 년 차에는 사용수명연장을 위한 정밀안전진단(Safety Test)
Table 7 Lifespan of the rolling stocks with discount rate(sensivity analysis)

\begin{tabular}{c|c|c|c}
\hline \multirow{2}{*}{ 할인율 } & $\begin{array}{c}\text { 유지보수비용 } \\
\text { 가중비율 }\end{array}$ & $\begin{array}{c}\text { 경제적사용 } \\
\text { 내구년한 }\end{array}$ & LCC비용 \\
\hline \hline \multirow{3}{*}{$2 \%$} & $0 \%$ & 32년 & $1,354,242,582$ \\
\cline { 2 - 4 } & $5 \%$ & 29년 & $1,363,928,790$ \\
\cline { 2 - 4 } & $10 \%$ & 27년 & $1,372,645,090$ \\
\hline \multirow{3}{*}{$4.1 \%$} & $0 \%$ & 46년 & $1,318,093,308$ \\
\cline { 2 - 4 } & $5 \%$ & 44년 & $1,346,096,544$ \\
\cline { 2 - 4 } & $10 \%$ & 41년 & $1,371,571,969$ \\
\hline \multirow{3}{*}{$5.5 \%$} & $0 \%$ & 72년 & $1,281,925,019$ \\
\cline { 2 - 4 } & $5 \%$ & 59 년 & $1,247,430,228$ \\
\cline { 2 - 4 } & $10 \%$ & 51 년 & $1,270,549,980$ \\
\hline
\end{tabular}

비용 2 억 5 천 만원과 5 년 후 안전진단비용 1 억 원을 예상했 고 사용 25 년차 부터는 매년 유지보수비용의 $10 \%$ 를 가산하 여 추정하였다. 경제적사용내구년한은 Fig. 2처럼 평균총비 용(Average Total Cost)이 최저점에 이르는 지점으로 이 지 점을 경제적내구년한(Economic life)으로 선택하는 것이 경 제적으로 유리하다[3]. VVVF제어 전동차 경제적사용내구년 한은 Table 8에서 보는것처럼 평균유지보수비용(Average Maintenance Cost)과 평균자본비용(Average Capital Cost)의 합계인 평균총비용(Average Capital Cost LCC)이 최저점에 이 르는 41년 차가 최적의 경제적수명(Optimum Econonic life) 에 해당된다. 41 년차의 평균유지보수비용이 $1,066,693,920$ 원 이고, 평균자본비용이 $304,878,049$ 원, 평균총비용이 $1,371,571,969$ 원이다.

\section{2 민감도 분석}

전동차 $\mathrm{LCC}$ 분석에 필요한 유지보수비용은 장기적인 유지 보수비용예측이 필요하며 이 비용예측은 할인율과 유지보수 비용가중치 비율에 따라 민감하게 반응하므로 이에 따른 민 감도분석을 각각 3 가지 조건으로 구분하여 분석했다. 실질 할인율 $2 \%, 4.1 \%, 5.5 \%$ (철도부문사업의 예비타당성조사 표 준지침서)세 가지와 25년 차부터 유지보수비용 가중치 $0 \%$, $5 \%, 10 \%$ 를 적용하여 민감도분석(sensivity analysis)을 하였다. 
Table 8 Average total cost (LCC) [W]

\begin{tabular}{|c|c|c|c|c|c|c|c|}
\hline $\begin{array}{l}\text { 년차 } \\
\text { (y) }\end{array}$ & $\begin{array}{c}\text { 유지보수비용 } \\
\text { (Maintenance cost) }\end{array}$ & $\begin{array}{c}\text { 가중치 } 10 \% \\
\text { (10\%added } \\
\text { from } 25 \mathrm{y}) \\
\end{array}$ & $\begin{array}{l}\text { 안전진단비용 } \\
\text { (safety cost) }\end{array}$ & $\begin{array}{c}\text { 누적비용 } \\
\text { (cumulative } \mathrm{M} / \mathrm{C} \text { ) }\end{array}$ & $\begin{array}{c}\text { 평균유지보수비용 } \\
\text { (Average } \\
\text { Maintenance Cost) }\end{array}$ & $\begin{array}{l}\text { 평균자본비용 } \\
\text { (Average } \\
\text { Capital Cost) } \\
\end{array}$ & $\begin{array}{c}\text { 평균총비용 } \\
\text { (Average Total-Cost) } \\
\text { [LCC] }\end{array}$ \\
\hline (A) & (B) & (C) & $\overline{\left(\mathrm{C}^{\prime}\right)}$ & $(\mathrm{D})=(\mathrm{B})+(\mathrm{C})+\left(\mathrm{C}^{\prime}\right)$ & $(\mathrm{E})=(\mathrm{D}) /(\mathrm{A})$ & (F)=125억/(A) & $(\mathrm{G})=(\mathrm{E})+(\mathrm{F})$ \\
\hline 1 & $312,568,794$ & 0 & 0 & $312,568,794$ & $312,568,794$ & $12,500,000,000$ & $12,812,568,794$ \\
\hline 2 & $510,235,528$ & 0 & 0 & $822,804,322$ & $411,402,161$ & $6,250,000,000$ & $6,661,402,161$ \\
\hline 3 & $761,581,554$ & 0 & 0 & $1,584,385,877$ & $528,128,626$ & $4,166,666,667$ & $4,694,795,292$ \\
\hline 4 & $767,312,824$ & 0 & 0 & $2,351,698,700$ & $587,924,675$ & $3,125,000,000$ & $3,712,924,675$ \\
\hline 5 & $834,890,656$ & 0 & 0 & $3,186,589,356$ & $637,317,871$ & $2,500,000,000$ & $3,137,317,871$ \\
\hline 6 & $906,599,852$ & 0 & 0 & $4,093,189,208$ & $682,198,201$ & $2,083,333,333$ & $2,765,531,535$ \\
\hline 7 & $958,577,201$ & 0 & 0 & $5,051,766,409$ & $721,680,916$ & $1,785,714,286$ & $2,507,395,201$ \\
\hline 8 & $929,349,711$ & 0 & 0 & $5,981,116,120$ & $747,639,515$ & $1,562,500,000$ & $2,310,139,515$ \\
\hline 9 & $941,759,282$ & 0 & 0 & $6,922,875,402$ & $769,208,378$ & $1,388,888,889$ & $2,158,097,267$ \\
\hline 10 & $945,743,801$ & 0 & 0 & $7,868,619,203$ & $786,861,920$ & $1,250,000,000$ & $2,036,861,920$ \\
\hline 11 & $947,338,066$ & 0 & 0 & $8,815,957,269$ & $801,450,661$ & $1,136,363,636$ & $1,937,814,297$ \\
\hline 12 & $952,929,439$ & 0 & 0 & $9,768,886,708$ & $814,073,892$ & $1,041,666,667$ & $1,855,740,559$ \\
\hline 13 & $873,505,011$ & 0 & 0 & $10,642,391,719$ & $818,645,517$ & $961,538,462$ & $1,780,183,978$ \\
\hline 14 & $941,568,599$ & 0 & 0 & $11,583,960,318$ & $827,425,737$ & $892,857,143$ & $1,720,282,880$ \\
\hline 15 & $900,618,904$ & 0 & 0 & $12,484,579,222$ & $832,305,281$ & $833,333,333$ & $1,665,638,615$ \\
\hline 16 & $922,163,223$ & 0 & 0 & $13,406,742,445$ & $837,921,403$ & $781,250,000$ & $1,619,171,403$ \\
\hline 17 & $1,064,900,895$ & 0 & 0 & $14,471,643,340$ & $851,273,138$ & $735,294,118$ & $1,586,567,255$ \\
\hline 18 & $1,042,842,877$ & 0 & 0 & $15,514,486,217$ & $861,915,901$ & $694,444,444$ & $1,556,360,345$ \\
\hline 19 & $1,026,112,062$ & 0 & 0 & $16,540,598,279$ & $870,557,804$ & $657,894,737$ & $1,528,452,541$ \\
\hline 20 & $1,029,585,264$ & 0 & 0 & $17,570,183,543$ & $878,509,177$ & $625,000,000$ & $1,503,509,177$ \\
\hline 21 & $1,028,173,193$ & 0 & 0 & $18,598,356,736$ & $885,636,035$ & $595,238,095$ & $1,480,874,130$ \\
\hline 22 & $1,029,987,968$ & 0 & 0 & $19,628,344,704$ & $892,197,487$ & $568,181,818$ & $1,460,379,305$ \\
\hline 23 & $1,038,180,754$ & 0 & 0 & $20,666,525,458$ & $898,544,585$ & $543,478,261$ & $1,442,022,846$ \\
\hline 24 & $1,053,133,635$ & 0 & 0 & $21,719,659,093$ & $904,985,796$ & $520,833,333$ & $1,425,819,129$ \\
\hline 25 & $1,065,450,524$ & $106,545,052$ & $250,000,000$ & $23,141,654,670$ & $925,666,187$ & $500,000,000$ & $1,425,666,187$ \\
\hline 26 & $1,079,613,473$ & $107,961,347$ & 0 & $24,329,229,490$ & $935,739,596$ & $480,769,231$ & $1,416,508,827$ \\
\hline 27 & $1,094,822,556$ & $109,482,256$ & 0 & $25,533,534,302$ & $945,686,456$ & $462,962,963$ & $1,408,649,419$ \\
\hline 28 & $1,110,726,308$ & $111,072,631$ & 0 & $26,755,333,241$ & $955,547,616$ & $446,428,571$ & $1,401,976,187$ \\
\hline 29 & $1,127,757,592$ & $112,775,759$ & 0 & $27,995,866,592$ & $965,374,710$ & $431,034,483$ & $1,396,409,193$ \\
\hline 30 & $1,133,188,110$ & $113,318,811$ & $100,000,000$ & $29,342,373,513$ & $978,079,117$ & $416,666,667$ & $1,394,745,784$ \\
\hline 31 & $1,143,829,482$ & $114,382,948$ & 0 & $30,600,585,943$ & $987,115,676$ & $403,225,806$ & $1,390,341,482$ \\
\hline 32 & $1,146,198,254$ & $114,619,825$ & 0 & $31,861,404,022$ & $995,668,876$ & $390,625,000$ & $1,386,293,876$ \\
\hline 33 & $1,146,310,603$ & $114,631,060$ & 0 & $33,122,345,685$ & $1,003,707,445$ & $378,787,879$ & $1,382,495,324$ \\
\hline 34 & $1,162,260,814$ & $116,226,081$ & 0 & $34,400,832,581$ & $1,011,789,194$ & $367,647,059$ & $1,379,436,252$ \\
\hline 35 & $1,176,854,633$ & $117,685,463$ & 0 & $35,695,372,678$ & $1,019,867,791$ & $357,142,857$ & $1,377,010,648$ \\
\hline 36 & $1,189,601,836$ & $118,960,184$ & 0 & $37,003,934,698$ & $1,027,887,075$ & $347,222,222$ & $1,375,109,297$ \\
\hline 37 & $1,202,288,256$ & $120,228,826$ & 0 & $38,326,451,779$ & $1,035,850,048$ & $337,837,838$ & $1,373,687,886$ \\
\hline 38 & $1,213,934,055$ & $121,393,405$ & 0 & $39,661,779,239$ & $1,043,731,033$ & $328,947,368$ & $1,372,678,401$ \\
\hline 39 & $1,224,410,644$ & $122,441,064$ & 0 & $41,008,630,948$ & $1,051,503,358$ & $320,512,821$ & $1,372,016,178$ \\
\hline 40 & $1,234,136,646$ & $123,413,665$ & 0 & $42,366,181,258$ & $1,059,154,531$ & $312,500,000$ & $1,371,654,531$ \\
\hline 41 & $1,243,881,333$ & $124,388,133$ & $\mathbf{0}$ & $43,734,450,725$ & $1,066,693,920$ & 304,878,049 & $1,371,571,969$ \\
\hline 42 & $1,253,384,651$ & $125,338,465$ & 0 & $45,113,173,840$ & $1,074,123,187$ & $297,619,048$ & $1,371,742,234$ \\
\hline 43 & $1,262,927,469$ & $126,292,747$ & 0 & $46,502,394,057$ & $1,081,451,025$ & $290,697,674$ & $1,372,148,699$ \\
\hline 44 & $1,272,793,076$ & $127,279,308$ & 0 & $47,902,466,440$ & $1,088,692,419$ & $284,090,909$ & $1,372,783,328$ \\
\hline 45 & $1,283,308,024$ & $128,330,802$ & 0 & $49,314,105,266$ & $1,095,869,006$ & $277,777,778$ & $1,373,646,784$ \\
\hline 46 & $1,294,954,732$ & $129,495,473$ & 0 & $50,738,555,472$ & $1,103,012,075$ & $271,739,130$ & $1,374,751,206$ \\
\hline 47 & $1,306,438,935$ & $130,643,893$ & 0 & $52,175,638,300$ & $1,110,119,964$ & $265,957,447$ & $1,376,077,411$ \\
\hline 48 & $1,318,346,228$ & $131,834,623$ & 0 & $53,625,819,150$ & $1,117,204,566$ & $260,416,667$ & $1,377,621,232$ \\
\hline 49 & $1,329,520,424$ & $132,952,042$ & 0 & $55,088,291,617$ & $1,124,250,849$ & $255,102,041$ & $1,379,352,890$ \\
\hline 50 & $1,339,201,322$ & $133,920,132$ & 0 & $56,561,413,071$ & $1,131,228,261$ & $250,000,000$ & $1,381,228,261$ \\
\hline
\end{tabular}




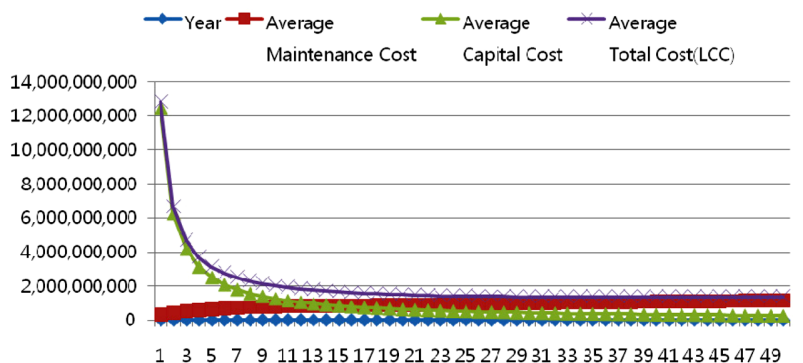

Fig. 5 Graph of average total cost(LCC) economic life

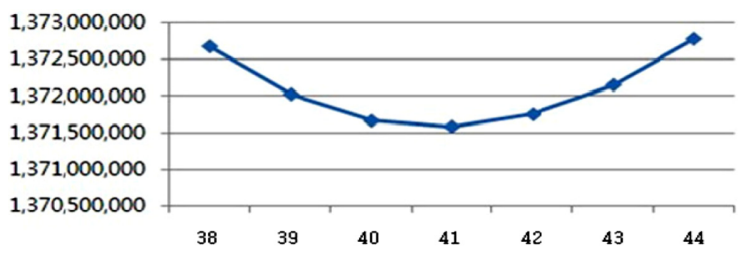

Fig. 6 Enlarge LCC curve at the lowest point

분석결과 내구년한은 Table 7처럼 장기간의 분석기간으로서 할인율에 의한 변동이 심하게 나타났다.

추정결과를 보면 유지보수비용가중비율이 높은 $10 \%$ 일 경 우 할인율 $(5.5 \%)$ 을 적용할 때 $\mathrm{LCC}$ 는 51 년으로 나타났고, 낮 은 할인율 $(2 \%)$ 을 적용할 경우는 27 년으로 낮은 할인율을 적 용 할수록 $\mathrm{LCC}$ 는 짧은 것으로 나타났다. 이것은 동액의 현 금흐름을 할인할 때 낮은 할인율을 사용하는 것이 높은 할인 율을 사용하는 것보다 현재가치가 크게 계산되기 때문이다. 예 를들면, 1 년 후의 1,000 원을 $5.5 \%$ 로 할인하면 $1,000 \div 1.055=$ 947 원이지만 $2 \%$ 로 할인하면 $1,000 \div 1.02=980$ 원이 되어 낮은 할인율 적용 시 예상비용의 현재가치는 상대적으로 크게 계 산된다. 본 연구의 목적인 전동차는 사용기간이 장기인 고정 자산이므로 할인율 적용에 따른 예상비용의 현재가치 변동성 이 크다. 따라서 세 가지 할인율에 따른 LCC를 분석하여 할 인율 변동으로 인한 LCC의 변화를 알 수 있도록 하였다.

\section{5. 결 론}

본 논문은 90 년 중반에 도입되어 운행되고 있는 서울메트 로의 VVVF제어 전동차에 대한 경제적사용내구연한에 대해 서 비용측면에서 분석하였다. 분석결과 유지보수비용 가중 치가 없는 경우에는 평균총비용(Average Total Cost)의 최저 점인 46년이 경제적사용내구년한으로 나타났고, 유지보수비 용 가중치가 $10 \%$ 인 경우에는 41 년이 경제적사용내구년한으 로 분석되었다. 노후화가 진행됨에 따라 부품교환비용과 검 사주기가 점증적으로 증가할 것으로 예상되어 유지보수비용 $10 \%$ 가중치를 부여한 분석결과가 합리적인 경제적내구년한 으로 판단되고, 향후 전동차의 내구년한연장의 기준점이 될 수 있다.

추정된 내구년한에 근거하여 전동차의 사용기간을 5 년 내 지 15 년간 사용기간을 연장하면, 자본투자를 연기함으로써 그
Table 9 Lifespan of rolling stocks of each oversea

\begin{tabular}{c|c}
\hline 운영회사 & 최소내구년한 \\
\hline \hline USA SEPTA EMU & 30 \\
\hline USA New York Subway & 40 \\
\hline Canada RAV EMU & 30 \\
\hline Turky Mamaray EMU & 50 \\
\hline Germany Hocodan EMU & 45 \\
\hline RATP & $20-40$ \\
\hline London Subway & $30-50$ \\
\hline Hongkong Subway & 35 \\
\hline
\end{tabular}

(출처: 도시철도차량의 내구년수에 대한 기초연구)

기간만큼 투자가 이연되므로 비용절감의 효과가 있다. 동액 을 투자한다고 가정했을 때 투자시점을 미래로 이연시킬수록 투자금액의 현재 가치가 작아져서 비용을 절감할 수 있다. 본 논문 가정(전동차편성당 가격 125 억, 할인율 $4.1 \%$ )을 적용했 을 때 현재가치계산식 $P V=C /(1+r)^{n}$ 에 의하여 현재가치를 계 산하면 5년 후 투자금액의 현재 가치는 $10,224,836,342$ 원, 10 년 후는 $8,363,782,258$ 원, 15 년 후는 $6,841,464,383$ 원으로 계 산된다. 해당금액을 현재투자 시의 금액 125 억과 비교하여 투자비용효과를 계산해보면 5년 연장일 경우 전동차 편성당 $2,275,163,658$ 원, 10 년 연장일 경우 $4,136,217,742$ 원, 15 년 연장일 경우 $5,658,535,617$ 원의 절감 효과가 있다.

74년에 도입되어 운용된 저항전동차는 법정 사용내구년한 에 의해서 이미 교체되었다. 신형전동차는 부식없는 스테인 리스(Stainless)차체, 고신뢰성의 SIV보조전원장치, 고성능의 교류모타(AC Motor), 전체중량의 경량화 등으로 구형전동 차에 비해서 기술측면에서 안전성·유지보수성·내구성이 획기적으로 향상되어 연장사용이 가능하다고 판단된다.

해외철도운영사의 경우 Table 9와 같이 사용기간이 최장 50 년까지 효율적으로 운용하고 있음을 볼 수 있다. 이와같 이 기술측면과 비용측면을 고려한 전동차의 효율적인 운용 이 필요하다.

이 논문은 16 년간의 유지보수비용을 근거로 50 년간의 비 용을 예측해야 하므로 정확성에 한계가 있음으로 25 년 운 용 후에 그 기간의 비용을 근거로 더 정확한 예측이 필요 하고, 향후 연구과제로서 서울메트로를 비롯한 국내 모든 운 영사의 전동차 관련비용을 분석하여 적정한 경제적내구년한 을 추정하여 현재의 기술수준과 성능에 맞는 합리적인 전동 차사용내구년한 설정이 필요하다.

\section{후 기}

이 연구는 서울과학기술대학교 교내학술연구비(일부)지원 으로 수행되었습니다.

\section{참고문헌}

[1] Rules code 9 on management of urban railway vehicle.

[2] N.W. Baek, K.S. Jang (2008) Railroad Engineering Hand- 
Book, Golden-bell, pp. 209-210.

[3] Benjamin S. Blanchard, Wolter J. Fabrycky (2011) Systems Engineering and Analysis, pp. 268-269.

[4] H.N. Jo, J.K. Lim, Y.M. Choe, K.H. Paek (2009) Life-Cycle Cost Analysis for Infrastructure Systems, Goomibook, pp. 6061.

[5] H.N. Jo, J.K. Lim, Y.M. Choe, K.H. Paek (2009) Life-Cycle Cost Analysis for Infrastructure Systems, Goomibook, pp. 59.

[6] Y. Song (2007) Acounting Principles, Woongji, pp. 372.

[7] Y.W. Lee (2009) Financial Management, WoonJjin PassOne, pp. 44-45.

[8] B.J. Park (2007) Modern Staistics for Business and Economics Using Microsoft Excel, Sigmapress, pp. 404

[9] Ministry of Land, Transport and Maritime affairs Notice 2006255.

[10] N.W. Baek. K.S. Kim (2006) Rolling Stocks HandBook, Kijeon Study.

[11] J.D. Chung, D.S. Bae (2005) Life-Cycle-Cost Evaluation of the Shunting Locomotive, Journal of the Korean Society for Railway, 8(3), pp. 260-266.

[12] H.K. Choi, S.S. Hwang( 2004) A Case Study on the Economic Analysis for a New Technical- Based Ventilation System Using LCC Technique, Architecture \& Urban Research Information Center, 4(4), pp. 143-150.
[13] S.M. Park, S. T. Kim (2008) "A research on the economical life-span setting of rollong stocks based on the LCC analysis".

[14] H.H. Park (2004) The Analysis Using LCC Approach for the Recommendation an Appropriate Maintenance Level, MA Thesis, In-ha University.

[15] B.J. Park (2007) Modern Statistics for Business and Economics Using Microsoft Excel, Sigmapress, pp. 417.

[16] Seoul Metro Rolling stocks regulation code.

[17] MicroSoft Excel.

[18] Railroad Safety Act.

접수일(2012년 7월 25일), 수정일(2012년 9월 27일), 게재확정일(2012년 10월 4일)

Su Young Chung : syc8102@ naver.com

New business Division. Seoul Metro. 432,Hyoryung-ro, Seocho-Gu, Seoul, 137-712, Korea

Won Young Lee : wonyiee @ Seoultech.ac.kr

Dept of Railway Management \& Polish Korea, Graduate School of Railway, Seoul National University of Science \& Technology, 232 Gongneung-ro, Nowon-gu, Seoul, 130-743, Korea 